\title{
Framing Space and Identity \\ - Examining Through the Space of Scholarship -
}

\author{
Jung-In Kim \\ Department of Architecture, Soong Sil University, Seoul, Korea
}

\begin{abstract}
This paper will discuss three different ways of framing relationships between identity and built forms mainly through the theoretical frame works of David Harvey, Christine M. Boyer, Jane M. Jacobs, Doreen Massey, Paul Rabinow, and Michel Foucault. From these scholars, this paper will argue the relationships between identity and built forms are categorized as such: "Becoming", "Politics of Difference", and "Construction of Self". Besides these three approaches of framing identity and built forms, relevant ideas will be drawn from the work of other scholars in so far as their theoretical positions relate and support these three key frameworks. To approach the critical points of each debate, these three categories are further analyzed by juxtaposing the epistemological positions between them. Through the comparisons, this paper illustrates the interrelationships and interdependence of these three categories whose discursive power gains rapid popularity in Western scholarships. By incorporating the three ways to view the relationship between built form and the identity of social groups, drawn is a suggestion for a broader imagining of new spatial identity.
\end{abstract}

Keywords : Neo-Marxism, Post-Colonialism, Post-Structuralism, Space, Identity

\section{INTRODUCTION}

In a reflection of urban experiences of the $20^{\text {th }}$ century, Richard Handler argues that the notion of identity and its use as a cross-cultural conceptual tool should not be regarded as a neutral framework. As historical analysis and ethnographic data suggest, the concept of identity is peculiar to the modern world, and its use is consistent with a widespread theory of culture and society that underpins a globally hegemonic cultural ideology (Handler, 1994). In discussing the formation of identity, he also notes that identities are constructed and reconstructed through historical actions including those of academics. In the same vein, David Lowenthal argues that even though idealizing individual creativity and innovation is only a normative tradition of Western culture, and not a universal value, a personalized Western sense of identity is now adopted and internalized around the world (Lowenthal, 1994). From these rather westernized views on identity, this paper elaborates the current identity frameworks that engage how we view of space not merely with the westernized lens, but also with the modern and globalized ones. In order to do this, chosen were several scholars who extrapolated the issues of identity relevant to our contemporary understandings of architecture and urbanism. Together with examining the space of scholarship through three different ways of framing relationships between identity and built forms, the debates and arguments will be made mainly through the theoretical frame works of David Harvey, Christine M. Boyer, Jane M. Jacobs, Doreen Massey, Paul Rabinow, and Michel Foucault.

\section{BECOMING}

In The Urban Experience (1985), David Harvey touches upon the issue of constructing group and private identity by exploring the concept of "the urbanization of consciousness." Harvey's use of this term suggests that the construction of 'identity' must be understood in relation to the accumulation of capital in an urban area. From the extrapolation of the theory of historical materialism, he proposes - as in the case of Portman's Bonaventure hotel analyzed by Frederic Jameson -to view the formation of identity through the unfolding of capitalism in urban areas. For him, study of the capitalist mechanism in an urban area is crucial to the examination of the way in which various social groups are formed and their hierarchies arranged by the "power of money." Harvey points out a cyclical pattern where these social formations of class, community, and family in turn affect the path and qualities of capitalist urbanization and feed back to alter our consciousness as well as the construction of our identity.(Harvey, 1985) Moreover, in his NeoMarxist formulation of identity, the state becomes the most important player; not only as a focus of place-bound loyalties but also as an apparatus that dictates to the populace specific ways of thinking and acting. Especially in the context of Neo-Liberalism from the mid-1970s, the spaces of the city, as the architectural revamp of Baltimore Inner Harbor showed, are often constructed through the massive mobilization of capital from the public to private sectors as consumerism in this mobilization masks the real domination of labor forces by "ruling class alliance." (Harvey, 1985) 
To a certain degree, foreseeing the rise of "Bilbao effect" Harvey argues, once the space of a city is organized as a result of capital investment, it assumes the "qualities of a text": A text which urban citizens have to learn to read to satisfy their personal needs and desires. During this interaction between capitalist space and individual adaptation certain qualities of the city's space create a symbolic world, which is both attractive and imposing to urban dwellers. As a response, through hierarchical order and often hidden significance, individuals fetishize the built environment and treat the symbolic world of the city as a 'thing' in itself to which he or she must conform. Harvey argues this festishizing process forcefully affects the formation of individual identity under the condition in which patterns of social life increasingly reflect the commodified thinking and doing. (Harvey, 1985) As Christine Boyer probes shopping spaces at New York's Battery Park as the imageconsumed city landscape in The City of Collective Memory (1996), so does Harvey's Neo-Marxist vision stare at fetishized spaces, and finds a close relationship between the symbolic world of the city and the commercialized consumption of identity. Harvey, using the term "the urbanization of capital," investigates capitalism's power to create blighted urban space, and explores a critical way to analyze the tacit mechanisms of entertaining an "urbanized consciousness" in our time. (Harvey, 1985)

In The Condition of Postmodernity (1989), Harvey clearly frames his methodological approach to address the issue of identity. Similar to Manuel Castells' concerns in The Urban Question (1972) two decades earlier, historical materialism offers framework for Harvey's debates on 'Postmodern conditions' which he sees as problematic to the unfolding of culture in the current time. Harvey argues the engagement with the historical materialism is a critical basis to understand "Postmodernity as an historical-geographical condition." He states, it offers the possibility

to launch a counter-attack of narrative against image, of ethics against aesthetics, of a project of Becoming rather than Being, and to search for unity within difference, albeit in a context where the power of the image and of aesthetics, the problems of time-space compression, and the significance of geopolitics and otherness are clearly understood. (p.359)

While his dualism later provokes severe criticism from geographers such as Doreen Massey (Massey, 1994), a renewal of historico-geographical materialism by Harvey reflected his epistemological accounts that dealt with issues of identity. Here, the approach is symbolized in the use of the term "Becoming." Under the newly forged capitalist condition of "Postmodernity," Harvey was critical of the essentializing and aestheticising trends in city space that devalued the human conditions of urban living, and which he claimed shattered values of 'Ethics' in the Enlightenment tradition. By reviving a Marxist analytical framework to view the built-environment, and through applying this to the cases of his "Postmodern" architectures, Harvey believes that structural analysis can promote a new version of human 'becoming' and therefore a new identity in the 'Enlightenment project.' (Harvey, 1989)

When he wrote Space Hope (2000), Harvey seemed to be aware the past criticisms of the Condition of Postmodernity. In Space Hope, his concept of human identity as "Becoming" complements his previous methodological approach that originally seemed to lack emphasis upon the issues of the female gaze and of the productive side in post-modernist thought. (Gregory, 1994) Espousing the conceptual model of "architect" as a desired human identity, he not only forwards historical materialism but also suggests new ways of thinking about the dialectical process of "Becoming." In this new human model, the "architect" becomes a figure who considers every contingency and coordinates historical making in the active relationship facing the 'other'- analogically he refers to architects as professional practitioners, who coordinate with the client, staff, and other factors relevant to the design process. He suggests,

I, as a political person, can change my
politics by changing my positionality and
shifting my spatiotemporal horizon. I can also
change my politics in response to changes in
the world out there. None of this can occur
through some radical revolutionary break. The
perspective of a long revolution is necessary.
[sic] No one can go it very far alone. But
positioned as an insurgent architect, armed with
a variety of resources and desires, some derived
directly from the utopian tradition, I can aspire
to be a subversive agent, a fifth columnist
inside of the system, with one foot firmly
planted in some alternative camp. (p.238)

This new human identity opens the historical possibility of, in his terms, "Dialectical Utopianism." The built environment is viewed in this sense as "a form of communication conditioned to occur without common rules," which he implies the dialectical making of our built world through sincere communication with the others who, as Harvey defines, do not follow the imposed rules of the game. (Harvey, 2000) In "Dialectical Utopianism," the most difficult task is to "translate" the abstract knowledge of historical vision into actual practices. Harvey says this translation is "materially grounded in social and ecological conditions but which nevertheless emphasizes possibilities and alternatives for human action through the will to create." (Harvey, 2000) Thus, Harvey's theory of human identity as "Becoming" not only looks for new creation in identity but is also fully aware of the existing conditions which are not of the individuals own choosing. (Harvey, 2000) Recognizing the importance of agents, Harvey argues that conflicts in 
the current social condition are an important mechanism by which to bring about a new 'social space' as a dialectical process, and the idea of utopia must be regenerated repeatedly by the spatial struggle that these agents take. Likewise, Don Mitchell argues that social struggle as a form of spatial contestation remains critical to the actual structuring and shaping of social justice. (Mitchell, 2003) As a social process, "Becoming" embraces the identity of "insurgent architects" who can translate the knowledge of "Dialectical Utopianism" and who take part in collective action towards change in the current space formed by Capitalism. (Harvey, 2000) Accordingly, these "architects" claim that their identity in consolidated Utopia is distant, but their identity of "Becoming" in ongoing regeneration towards it may not be.

\section{POLITICS OF DIFFERENCE}

Borrowing Iris M. Young's concept of "Politics of Difference," Dolores Hayden comments that struggles over social and political issues, rather than physical ones, are the center of urban landscape history. In her studies of seemingly "ordinary" buildings and urban spaces in L.A., Hayden gives primary importance to the political and social narratives of place and to the everyday lives of under-privileged people.(Hayden, 1995) Similarly, in her book, Edge of Empire (1996), Jane M. Jacobs argues the making of identity is a political process, and when it is applied to the built environment this process often takes notion of 'heritage' as the central stage. Taking on the ecotourism center at Brisbane City, She says the link between the idea of heritage and the built environment "by no means implies simply that 'heritage sites' symbolize certain bounded values and beliefs, but that the very transformation of these places into 'heritage sites' is a process whereby identity is defined, debated, contested, and therefore often challenges social orders."(Jacobs, 1996) For her, the transformation that places undergo in the 'politics of recognition' is a key arena in which to define identity. In this sense, identity is a dynamic process of creation in which diverse memories of the past are selectively resuscitated for the present purpose of political visibility.

While Jacobs' post-colonial geographies suggest an intriguing reshaping process of identity in the present, she emphasizes that politics of identity are often about specific places which are by no means sealed off from broader spatialities. (Jacobs, 1996) Jacobs" "politics of difference" then, undeniably connotes a 'politics of place,' which parallels the argument in Doreen Massey's Space, Place, and Gender (1994), where Massey argues that 'social space' always has a vast complexity of interlocking and articulating nets of social relations. Along these multifaceted social relations of space, Massey also postulates the notion of 'place' which is formed out of diverse human interactions and cultural exchanges both at the local and global level. Like space, Massey never sees 'place' as a static concept but rather as a flexible mode of social and spatial interlinking, and she further argues overcoming the notion that place is static will produce a new definition of identity in 'social space.'(Massey 1994) Accordingly, in this flexible mode of investigating identity and place, Jacobs' three ways of viewing social interactions - hybridity, appropriation, and essentialism- are a sophisticated illustration of the formation of identity that emerges at the intersection of imperialism and globalization.

In terms of the cultural notion of appropriation, Jacobs argues that "even though it is commonplace to read 'appropriation' as the commodification and contamination" of colonized cultures, this general view is not always correct. Jacobs sees the massive criticism of tourism and heritage industries in part driven by the anxiety that such industries commercialize the authentic identity of culture and in so doing "wrench it away from its point of origin." In the appropriation of native cultures she continues that the heritage and tourism industries have been considered a threat to the survival of more authentic places and social identities.(Jacobs, 1996) However, as Jacobs shows in the case of Brisbane's eco-tourism case, appropriation is by no means a predictable cultural exchange within the tourism and heritage industries. Conversely, they can, rather than being a threat to 'authentic' places or identities, promote nostalgia which further elevates imagined 'authentic' places. As identities are appropriated through commodified forms of invention, such notion as a "place called home" (Massey, 1996) draws complex pictures allowing appropriation and contestation from the tourism and heritage industries.

Regarding hybridity, Jacobs also cites this Brisbane case as an example not only of western appropriation of indigenous culture, but also as an indigenous engagement with such western desires. (Jacobs, 1996) In her theory of hybridity, she argues that the agency of the colonized subject is one of most important elements to explore. She states:

In thinking through the postcoloniality of the hybrid form it is often too easy for agency and intentionality to be displaced...Hybridity was not about the dissolution of difference, or even only about destabilizing the construct of Self and Other, but about renegotiating the structures of power built on difference. The political weight of this hybrid space resides not simply in its surface form and in its effects, but also in the intentional politics of its production...Attending to such intention, even while it might fracture into a disorderly effect, is a necessary component of a postcolonial critique. (p.162) 
In her notion of hybridity, Jacobs argues that postcolonial theories of hybridity are no longer unconscious by-products of colonialist constructs. In fact, the theory of hybridity has to be remade through a creative use of the colonial past by the colonized in the service of a postcolonial future.

Besides, Jacobs studies the irony of essentailized 'politics of difference' such as "return to Nature" in the Old Swan Brewery in Perth, Australia. Jacobs argues, even though top-down colonial discourse offers "eroticized," "aestheticised" and commodified appropriation, this governmental discourse can also be challenged from a bottom-up movement as in the form of occupying the land as well as in the notions of essentialist pre-colonial identities.(Jacobs, 1996) She continues, despite the negative side of essentialist politics, cultural essentialism, like claims of a native's sacred place, can be the only feasible tool to assert the native's political visibility. Furthermore under a different context, as Jacobs explains through the commodified development in Spitalfields in London, essentialized constructs of identity and place are also open to reinvention, adaptation, invigoration and re-appropriation at the hand of the colonized. (Jacobs, 1996) In this vein, Jacobs argues that the strategy of fixing identity in place is also important for marginalized groups who want to distinguish their claims from hegemonic power. Jacobs adds, "it is one thing for such a generalization to unsettle nostalgia for empire or the violence of some nationalism; it is another thing when it also compromises the claims upon land by colonized groups who are still intensely marginalized." By studying the uneven social conditions and contexts that these essentialised identity constructs are under, she proposes a theoretical reconsideration of identity formation based on a different political consequence which this essentialism might bring. (Jacobs, 1996)

In her book, Edge of Empire, Jane M. Jacobs explores how spaces of otherness are present within complex geographies of globalization. Through her four case studies, Jacobs argues that, under the Neo-Liberal global regime, identity is reconfigured in the post-colonial geography where the notion of hybridity, essentailism and appropriation are integrated. This shaping of identities is presented within a political terrain where localized identity claims actively interact with the globalizing forces of the current time frame. (Jacobs, 1996)

\section{CONSTRUCTION OF SELF}

From "incitement to speak" to "immense verbosity," the discursive practices toward the creation of modern institutions appear to entirely frame the social relations of individuals and groups. As Patrick Joyce has illustrated in his book, The Rule of Freedom (2003), newly conceived buildings and institutions in the $19^{\text {th }}$ century, from public parks to libraries, created the 'disciplinary gazes' which focused upon creating docile but productive working classes. The built environment thus became the apparatus by which to educate the desired and respectable poor. (Joyce, 2003)

Joyce's British case studies also apply to the built environment in the colonial context. Timothy Mitchell shows that 'en-framing' became a political technology of colonial governments as a method of controlling and dividing up the colonized. Mitchell shows the construction of barracks or the rebuilding of villages to reveal this colonial technique of 'en-framing'. This term itself, Mitchell argues conjures up the order that forms rooms, courtyards, and buildings specified in minute detail, and which introduces "space as something apparently abstract and neutral, a series of inert frames or containers.'(Mitchell, 1991) To add Mitchell's point, Paul Rabinow also describes that modern urbanism and the total social planning under the French domain in the $19^{\text {th }}$ century, particularly internal struggles within the BeauxArts tradition, embodies forms to normalize the population through the regularization of space. (Rabinow, 1989) According to these scholars, the built environment was then locked in a maze of a pervasive technological grid, which shaded by immense pressure from discursive forces of social norms and forms.

Likewise, in what Michel Foucault termed, "meticulous rituals of power," the development of social technology and human science in the $19^{\text {th }}$ century in turn created modern individual 'self' within the matrix of "taken-forgranted rules." Expanding this Foucaultian view to architecture and urbanism, the already mentioned three scholars- Mitchell, Joyce and Rabinow- argue the creation of 'self' is intricately meshed in our consciousness of the 'normal' which has been constructed by existing social values and habits of a unquestioned regime. In this regard, the novelty of the Foucaultian perspective resides in the pervasive omnipresence of "Bio-technico-power" and the 'constructedness' of 'self.'(Hubert Dreyfus and Paul Rabinow, 1983) In other words, the relation between 'self' and "Bio-technico-power" implies the specific mechanisms of technology through which power, like social norms, are articulated on the individual body. And this relationship shapes our notion of 'self,' identity, and recognition of others by complex social processes between rejections and acceptances.

In this framing of human identity, power is less of a force of direct regulation or amelioration of individual 'self,' but rather an invisible technique treating it as matter to be formed and normed at will through, what Rabinow calls, "voluntarist program." (Rabinow, 1989) In this urbanism, the spontaneity of 'self', and its visible expression in the public space served as an index of the self-regulating urban community policing itself through inherent social codes of conduct. (Joyce, 2003) Now, the body becomes the manifestation that situates each individual in a historically established 'consent,' and dictates our habit of conformity. 
In French Modern(1989), Rabinow also suggest this normalizing process in his use of the term, "middling modernism," by which he means,

Universalizing social norms and economic
stratification gradually displaced the
disciplinary tactics of hygiene and
environmentalist localisms in defining and
enforcing social reality. The plan of life was
passing from a bacteriological and class
phase to a functionalist and normalizing
sociological one. (p.347)

Under this 'life plan' transition, he illustrates through the history of French colonization in the $19^{\text {th }}$ century, that social 'norms' operated upon technocratic world-views eliminating all differences except for scientifically framed relations to social values. (Rabinow, 1989) This new social engineering adjusted historical and natural understanding of human beings into emerging technological trajectories. Here, pragmatic knowledge was concentrated upon the management of the population, and professional experts supported emerging technical sophistication to enhance the legitimacy of social order. "Efficiency, science, progress, and welfare" came to the forefront of social values and emphasized an anonymous space of regulation and rationalization. (Rabinow, 1989) Accordingly, this neutralizing process was applied to the construction of 'self' that accepted unquestioned social customs and values, and reproduced a naturalized view of the world. (Foucault, 1980)

Rabinow's analysis suggests that, when historical inquiry of 'self' is concerned, there is a sudden conceptual rupture in the Foucaultian view that breaks from the modern understanding of human 'self' as the center of universe. In his two seminal volumes, The History of Sexuality (1978) and Discipline and Punish (1977), Michel Foucault focused specifically upon modern institutional development that brings a disciplinary space where the political technology of body becomes a 'policing' matter from the $18^{\text {th }}$ century - "not the repression of disorder, but an ordered maximization of collective individual forces." (Foucault, 1990; Foucault, 1995) To further his argument and to engage one of the most crucial institutional technologies in the modern world, Judith Allen applies Foucault's power concept to the modern state as being "characterized by its concerns with both the whole of the social body and with the bodies of the individual it governs."(Allen, 1996) This new mode of governing 'polices' and 'promotes' the social body through administrative means and advocated totalization and industrialization through science and rational (space) planning. (Rabinow, 1989) As such these became the emerging social and technical means for the state to generate the governed 'self' as part of collective entity within the state boundary.

Patrick Joyce describes this state technique as Govenmentality, by which he explains it as "a kind of intellectual machinery or apparatus for rendering reality thinkable in such a way that it is amenable to political programming." (Joyce, 2003) For Joyce, this political programming is epitomized by his formulation of the "rule of freedom" which he assigns development of British liberal citizenship to techniques of Govenmentality including those of architecture and urbanism in the $19^{\text {th }}$ century Britain. (Joyce, 2003)

Writers influenced by Foucault's idea of 'social construction' show the modern 'self' has been created through the institutional technique to take hold of society's basic requirements, to care for each individual's biological needs and to improve general welfare. This Foucaultian view also sees that identity of 'self' is captivated in the administrative means and controlled space of the modern state institutions. (Hubert Dreyfus and Paul Rabinow, 1983) Hence, individual identity is nested in the imperceptible collusion of institutionalized knowledge and power which aimed at governing each member of populace, managing them, and inventing their lives through the construction of desirable 'self.'

\section{CRITICAL DEBATES}

\section{Becoming}

David Harvey's historical materialism and the human identity as "Becoming" recognize that the making of built environment and the identity associated with it are the outcome of structural reality in political economy. This view demystifies the idea that large urban projects like the Harbor Place in Baltimore and the Battery Park in New York are operated in the public interest, and makes clear that class interests are always driving force. In turn, classconsciousness helps to understand the material reality of the city, and exposes the real relations of power which the built environment (architecture being an important part of it) was serving and in which it is deeply and inextricably implicated. Moreover, the Neo-Marxist view of capitalist space notices that the private ownership of property and the imperatives of capital accumulation place real limits on any sound development of human identity, thus the current development of identity debates is manipulated on behalf of the dominant class interests. (Harvey, 1990)

In political economic analyses ranging from the production side to the collective consumption side, the state role in capital accumulation is also elaborated upon by this view which links state efforts of legitimizing capitalism to the fetishized identity formation in space. (Smith, 1996; Castells, 1977) Harvey and others, especially Christine Boyer, strenuously point out current entrepreneurial cities and their built environments have produced distorted human identity that seem to always be in the service of capital and subsumed in fetishized desires.(Boyer, 1996) In a sense of what Manuel Castells expresses as the widening gap of "net and the self," Boyer summarizes the contradiction of modern 'self' as that, contrary to homogenizing trend in global space - termed as architecture of "nudity"-, individual identity is fragmented into hierarchicalized enclaves according to the 
order of capital.( Castells, 2000) Focusing on efforts towards visual domination and entertainment in architecture, this view further recognizes that the commodified formation of 'self' becomes "the style, the look, or the image" and identity as a structure of feeling is incorporated into the marketized urban consciousness.(Boyer, 1996) Thus, these scholars' reading of built environment shows the problematic notion of identity in a desire expressed in capitalism.

In this vein, the strength of Neo-Marxist view on space and identity takes a firm direction towards universal human values: that is, historical materialism as an existential process searches for the model of emancipated human identity without the domination by capital. As a response to a capitalist society, it contrasts with the current formation of human identity which increases impoverishment of the poor, human-right violations, and environmental deteriorations. Plus, it offers a useful tool to criticize the currently rampant production of uneven geography, international and national division of labor, and the weakening of working class positions. Working toward basic human conditions, the spatial examination of "Becoming" forcefully criticizes systemic domination of capitalism which limits the full realization of human identity.

However, identity in the frame of historical materialism, no matter how different questions of identity are viewed, seems to be a product of the superstructure. This notion of superstructure, especially from the view of poststructuralism, can be a problematic epistemological tool since one form of representation to describe reality might be anchored in a certain class perspective. Likewise, the epistemological question involved in the debate of NeoMarxist paradigm kenneled down to anxious questions like "How do we know what we know" which questions the nature of knowing reality. If such question leads to answers like "we know from a particular construction of the real" or "we do not have any means to know the real," then Neo-Marxist framing of human identity as a process toward universal human value based on 'material reality' becomes an unstable epistemological tool.(Baudrillard, 1994)

On the other hand, Doreen Massey who addresses Harvey's The Condition of Postmodernity, counters his identity formulation in the built environment as offering too static of a framework that hardly captures the actual local formation of identity. From a politically left and feminist point of view, Massey criticizes Harvey's argument on "Becoming" that seems to be based on his "modernist" master narration of place and identity.

Massey begins her criticism on Harvey's philosophical dualism of Time connoting "Becoming," whereas Space connotes Being. For her, this dualism implies certain rigidity in the views on identity and place formation. She argues that the grasp of Being and 'Space' in an essentialist (Heideggerian) mode is doubtable since Harvey's argument involves too inflexible a conceptualization to apply real situation of the world.
(Massey, 1994) At the same time, Massey is also skeptical of Harvey's attribution to 'place' as a nostalgic and aesthetic mode, which in her view leads to a simplifying argument that the 'place' is 'unethical' and one which defies universal values. (Massey, 1994) For Massey, the generalization of 'place' hardly suggests any sophisticate framing, thus by saying "it is people, not places in themselves, which are reactionary or progressive," Massey argues that our experience and interpretation of 'place' needs to be understood in more inclusive ways. (Massey, 1994) This leads her to claim that the inclusiveness of 'place' has to be similar to that of 'identity' which unlike Harvey's "Becoming" involves multiple social groups of different gender, race, ethnicity, and sexual preference.

\section{Politics of Difference}

Meanwhile, "Politics of Difference" points out that modernist principles of thought exclude minority groups as agents of historical experience and leave out their life story as valid focus of study. This criticism, along with feminist writings, addresses the issue that the dominant way of knowing has often been unquestioned epistemological practice and a single paradigm of knowledge: i.e., the view from western, white, male, heterosexual has been a grand narration hiding unequal social relationships of domination and subordination. (Sandercock, 1998) In other words, by studying underprivileged groups' voices and status as active agents, "Politics of Difference" points out that framing identity in other paradigms of knowledge have been either racial, masculine, or culturally specific ones, and this framing has been written only from the point of view of hegemonic social groups. Against this, "Politics of Difference" brings out the agents' ability of claiming their own voices and refuses to stay silent on the part of those who have been treated unfairly in social systems. It tackles the problem of the exclusion of under-privileged groups as its epistemological focus and articulates questions of identity under the conditions of unequal human relationships.

From the addition of underrepresented social groups, "Politics of Difference" thus seeks to improve our understanding of architecture and urbanism. As illustrated in Jane M. Jacobs' Edge of Empire (1996), the importance of discussing non-mainstream historiographies which include the exploration of hybridity, appropriation, and essentialism, is directly related to social processes that produce certain views on the built space.(Jacobs, 1996) Issues such as: who benefits from the production of a certain identity, who has the authority to represent it, and whose representation of identity prevails in built forms show that identity captured in post-colonial lens is not space-neutral. This awareness leads to the importance of political content in architecture in which discursive power and legitimacy of one single dominant way of seeing are often entrenched. In this epistemological approach, architecture and urbanism are often viewed as outcomes 
of a social process steeped in contest, appropriation, as well as cooptation between dominant and subordinated social groups.

On the other hand, the critique of multiple human identities and their claims comes from another postcolonial scholar, Teresa Caldeira. In her criticism of Iris M. Young's "Politics of Difference," Caldeira argues, Young sees city life as the bringing together of strangers, whose ideal is openness to unassimilated otherness. In principle, these ideals are "incompatible with any kind of hierarchical order and can be conceived under the assumption of a universal equality of citizens that constitute modern Western societies." Caldeira explains that Young's argument seems to be a normative ideal and to take up 'unassimilated-ness' as a preconditioned social relation of "difference without exclusion." Here, Young's "Politics of Difference" is limited to the context of criticizing western ideals of community which deny difference between subjects and operate to exclude those who have different social experiences. Young considers this idealization of community as the force to homogenize and fuse people with one another, and which she regards as a somewhat misplaced model of democratic politics. This argument, paralleling the cases studied by Dolores Hayden's The Power of Place (1996) and Jane Jacobs' The Death and Life of Great American Cities (1961), postulates the impossibility of modern ideal community and resuscitates the notion that experiences of various social groups have been different. (Young, 1990)

From this argument, "Politics of Difference" demands recognition of the unique identity of each group and its distinctiveness from others. However, even though "Politics of Difference" still refers to a principle of social equality, this involves a certain essentialist notion that aligns identity of groups to an unassimilated uniqueness. (Young, 1990) Caldeira argues this insistence of 'difference' is exactly the model used to build fortified enclaves and retreat to walled communities, which she shows in her book, City of Walls (2000). In Young's model of "Politics of Difference," differences should remain unassimilated, and they should not disappear under any "fiction" of a universal belonging. In this regard then, "Politics of Difference" can be located directly opposite the position of 'universality' of human existance which is founded on the human principles of right, co-solidarity, freedom, liberation, justice, and equality: the position not only shared by David Harvey and other Neo-Marxists but also Edward Said and Arjun Appadurai.(Said, 1993; Appadurai, 1996; Appadurai, 2001)

\section{Construction of "Self"}

Staying out of Neo-Marxism and Post-Colonialism, Foucaultian analysis of 'self' yet exposed another crisis in the Enlightenment vision of 'universal self.' It addresses the notions of 'constructedness' in modern identity formation where the 'subject' is no longer a universally fixed concept, and extrapolates nature of 'subjectivity' through genealogical tracings. (Foucault, 1980; Foucault,
1990) In this interpretive analysis, Foucaultian thought problematizes the modern theory of knowing the 'self,' arguing that the modern conception of a transcendental "I" base on a priori concept needs to be readdressed from different angles; that is, Foucaultian thinkers take on the modernist epistemological approach toward 'self' which has privileged the rational discourse of Enlightenment tradition as the sole avenue of knowledge. With this understanding, whether the grand-narration is that of progress and triumph of reason, or the Marxist drama of class conflict culminating proletarian revolution, this way of telling story is considered an imprisoning and totalizing discourse.(Sandercock, 1998) Foucalutian thinkers reject the uni-linear description of 'self,' saying that the analytical mode has to address socially constructed human identity since this focus will raise serious epistemological questions on the taken-for-granted practices of our daily lives.

Epitomized in the observation of Jeremy Bentham's Panopticon, which mostly built in colonial territory, Foucaultian analysis of space provides a critique of western modernity. (Foucault, 1995) Here, controlling and disciplining their populations by sanctioning authority over knowledge as well as by practicing the human science directs the built environment in a specific course. From the observation of historical developments of hospitals, prisons, libraries, or museums in the $19^{\text {th }}$ century, a Foucaultian analysis calls these institutional establishments a standardization of scale serving to homogenize space, "substituting space for what has been called place." (Joyce, 2003) Thus, looking beyond identity formation under the face of universality and objectivity, this view is critical of the presumed rationality of our discourses and practices. It reveals that the distinctively modern form of normalizing and disciplinary power includes the forming modern 'self' of ordinary citizens who internalize the categories and values of the invisible power regime. Finally, it strenuously points out that the modern, self-examining, self-policing, selfdisciplining 'normal' individual was created in the development of this 'bounded self' enmeshed in architecture and urban space. (Caldeira, 2000)

Yet, critique of space framed by "Construction of Self" comes first from the Neo-Marxist perspective. As Mike Davis argues, the adaptation of postmodern thought for inner city development has often led to misreading of contemporary space, which in turn leads to a relativism of cultural politics that becomes a tool of deployment toward entrepreneurial purposes. One of most serious consequences of this trend is the removal of important systemic issue like class struggle from the public consciousness. Davis argues that postmodern visions often "tend to collapse history into teleology and glamorizing the reality" and by which 
he illustrates that numerous celebrated architects of the post-modernist group lack a perspective of structural issues, and frequently produce two dubious forms of resistance against the all encompassing eye: one is commercialized "multiculturalism," a theme frequent in large shopping malls, and the other is Frank Gehry's sort of "popularism."(Davis, 1992) He argues these two surface treatments of the built environment are subsumed in the logic of capital, and ignore the direct and outright phenomena of city space that provide defensive enclaves as described in his studies of "Fortress L.A."

Moreover, within post-modernist thought itself, there arises internal criticism of Foucaultian space with the intention to reconfigure power relationships into ordinary daily practices. This view is famously framed in Michel De Certeau's The Practice of Everyday Life (1984) in which he argues that Foucault's all encompassing gaze has a few loopholes and doesn't explore well a way out from the matrix of disciplinary power. From the Foucaultian notion that power is anchored in the micro-practice of everyday life, De Certeau establishes a contrast between the panoramic view of great metropolis and the migrational practice of pedestrian walking by the route and detours.( De Certeau, 1984; Guy Debord, 1983) In this resistive activity, De Certeau, along with Guy Debord, espouses the city experience of "detournement" and suggests a revolutionary impulse in the everyday spatial practice in the city. This view notices the disappearance of agents often founded in Foucaultian framework and emphasizes street experience as a form of fluid and mobile possibilities of everyday appropriation.(Gregory, 1990) In a hybrid and liminal space of streets, the pedestrian vision is how "Governmentalized Space" is lived out by everyday resistance in which, from Patrick Joyce's terminology, "the freedom beyond freedom" is present and made into action with intention to elude the totalizing gaze.(Joyce, 2003)

\section{CONCLUSION}

Through the discussion of works of the scholars who theorize the relationship between built forms and the human identity formation, this paper has placed key arguments in three categories: human-spatial identity framed in "Becoming," "Politics of Difference," and "Construction of Self." These three ways of looking at identity and built forms have a fundamentally reciprocal nature and complement each other's frame of view, whose strength in one epistemological approach can be the other's limitation and vice versa.

To frame issues of human identity in the built environment, there is fundamental paradox. That is, on the one hand, human identity is a bounded concept in which recognition of any social space will remain a powerfully seductive mirage, as we discovered from the rising personal demands of belonging to various social spaces. Everyone and everyplace needs to be anchored by some solid location, either institutions like family and nation, or social relations like class and gender. On the other hand, however, this bounded identity has not always stayed in one place, especially under the condition of what Manuel Castells calls "Space of Flow" where current information technology radically changed our mode of communication and cultural expression.(Castells, 2000) This unbounded nature of identity has been the focus of this debate through investigating each scholarly framework: "Becoming," "Politics of Difference," and "Construction of Self."

In terms of articulating these three methods, a reflection of each category is found in broader concepts of human relationships ranging in scale from the personal to the transnational. That is, the relationship between identity and built forms needs to be readdressed both at the micro level of personal experience as well as at a larger extent of achieving universal values. This reformulation starts from various social practices such as appropriation, contestation, and hybridization, and confers a new energy and power to build a constructive identity in every social group. In the combination of these three views on human identity and the built environment, new sort of human efforts - such as consolidation of human recognition of each other, and the questioning of currently unchallenged social norms and built forms empower one to "live our lives as lived" and offer an opportunity to create a new kind of architectural and urban space in which everyone can become active agents. Maintaining a productive engagement of these three theoretical paradigms with the actual forms of the social practices, one can still glimpse a territory where another way of seeing ourselves awaits.

\section{REFERENCES}

Appadurai, A. (1996) Modernity at Large. Minneapolis: University of Minnesota Press,.

Baudrillard, Jean. Simulacra and Simulation. Ann Arbor: University of Michigan Press, 1994.

Boyer, Christine M. The City of Collective Memory: Its Historical Imagery and Architectural Entertainments. Cambridge, MA: MIT Press, 1996.

Caldeira, Teresa. City of Walls. Berkeley: UC Press, 2000.

Castells, Manuel. The Rise of the Network Society. 2nd ed., Malden, MA: Blackwell Publishers, 2000. 
Castells, Manuel. The Urban Question: a Marxist approach. Cambridge, MA: MIT Press, 1977.

Davis, Mike. City of Quartz: Excavating the Future in Los Angeles. New York: Vintage Books, 1992.

De Certeau, Michel. The Practice of Everyday Life. Berkeley: University of California Press, 1984.

Debord, Guy. The Society of the Spectacle. New York: Zone Books, 1983.

Dreyfus, Hubert, and Rabinow, Paul. Michel Foucault: Beyond Structuralism and Hermeneutic. Chicago: U. Chicago Press, 1983.

Foucault, Michel. Discipline and Punish: the Birth of the Prison. New York, NY: Vintage Books, 1995.

Foucault, Michel. Power/Knowledge: Selected Interviews and Other Writings 1972-1977. New York: Pantheon Books, 1980.

Foucault, Michel. The History of Sexuality: An Introduction. New York, NY: Vintage Books, 1990.

Gregory, Derek. Geographical Imaginations. Cambridge, MA.: Blackwell Publishers, 1994.

Handler, Richard. Is "Identity" a Useful Cross-Cultural Concept?, in Commemorations: The Politics of National Identity, John R Gillis, ed., Princeton: Princeton University Press, 1994.

Harvey, David. The Urban Experience. Baltimore: the Jonhs Hopkins University Press, 1985.

Harvey, David. The Condition of Postmodernity: An Enquiry into the Origins of Cultural Change. Malden, MA: Blackwell Publishers, 1990.

Harvey, David. Spaces of Hope. Berkeley: University of California Press, 2000.

Hayden, Dolores. The Power of Place. Cambridge, MA: MIT Press, 1995.

Jacobs, Jane M. Edge of Empire: Postcolonialism and the City, London; New York : Routledge, 1996.

Joyce, Patrick. The Rule of Freedom: Liberalism and the Modern City. London: Verso, 2003.

Lowenthal, David. Identity, Heritage, and History, in Commemorations: The Politics of National Identity, John R Gillis, ed., Princeton: Princeton University Press, 1994.

Mandelbaum, Huigi Mazza, and Burchell, Robert et al, ed. Exploration in Planning Theory. New Brunswick, NJ: Rutgers University Press, 1996.

Massey, Doreen. Space, Place, and Gender. Minneapolis: University of Minnesota Press, 1994.

Mitchell, Don. The Right to the City: Social Justice and the Fight for Public Space. New York: Guilford Press, 2003.

Mitchell, Timothy. Colonising Egypt. Berkeley: University of California Press, 1991.

Rabinow, Paul. French Modern: Norms and Forms of the Social Environment. Cambridge, Mass.: MIT Press, 1989.

Said, Edward. Culture and Imperialism. New York: Vintage Books, 1993.

Smith, Neil. The New Urban Frontier: Gentrification and the Revanchist City. New York: Routledge, 1996.
Snadercock, Leonie. Toward Cosmopolis: Planning for Multicultural Cities. Chichester, UK: John Wiley \& Sons, 1998.

Young, Iris M. Justice and the Politics of Difference. Princeton: Princeton University Press, 1990.

(Date of Submission : 2009.11.21) 